\title{
APSA Members Awarded Guggenheim Fellowships
}

\section{ABOUT THE GUGGENHEIM FELLOWHIP}

United States Senator Simon Guggenheim and his wife established the John Simon Guggenheim Memorial Foundation in 1925 as a memorial to a son who died April 26, 1922. The Foundation offers Fellowships to further the development of scholars and artists by assisting them to engage in research in any field of knowledge and creation in any of the arts, under the freest possible conditions and irrespective of race, color, or creed. The Foundation receives between 3,500 and 4,000 applications each year. Although no one who applies is guaranteed success in the competition, there is no prescreening: all applications are reviewed. Approximately 200 Fellowships are awarded each year.

Often characterized as "midcareer" awards, Guggenheim Fellowships are intended for men and women who have already demonstrated exceptional capacity for productive scholarship or exceptional creative ability in the arts.

\section{ADAM J. BERINSKY}

Adam J. Berinsky is a professor of political science at Massachusetts Institute of Technology. Berinsky received his BA from Wesleyan University in 1992 and his PhD from the University of Michigan in 2000. He is a specialist in the fields of political behavior and public opinion. While he is primarily concerned with questions of representation

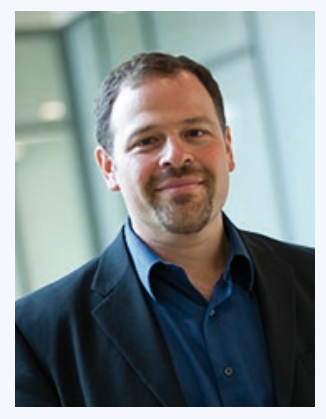
and the communication of public sentiment to political elites, he has also studied public opinion and foreign policy, the continuing power of group-based stereotypes, the effect of voting reforms, and the power of the media.

He is the author of In Time of War: Understanding American Public Opinion from World War II to Iraq (University of Chicago Press 2009) and Silent Voices: Public Opinion and Political Participation in America (Princeton University Press 2004) and has published articles in many academic journals. He has won several scholarly awards, is the recipient of multiple grants from the National Science
Foundation, and was a fellow at the Center for Advanced Study in the Behavioral Sciences. He currently edits the University of Chicago Press's Chicago Studies in American Politics book series. He is also the founding director of the MIT Political Experiments Research Lab.

While a Guggenheim Fellow, Berinsky will study how political rumors spread and how they can be effectively debunked. By examining the fundamental problem of democratic citizenship-namely the enduring obstacle of political misinformationhis project will advance the study of mass political behavior in new ways and will have important implications for the conduct of politics in the twenty-first century.

\section{ROXANNE L. EUBEN}

Roxanne L. Euben is the Ralph Emerson and Alice Freeman Palmer Professor of Political Science at Wellesley College. Her scholarship has helped pioneer a new area of inquiry called

"comparative political theory." Rather than taking political theory as coextensive with a specific canon of books, a particular civilization or mode of thinking, this

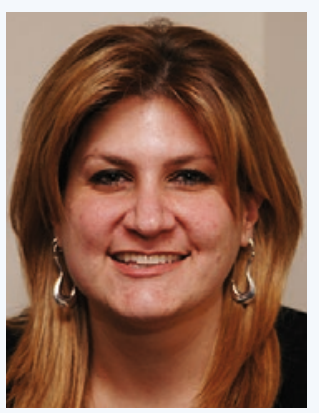
approach takes political theorizing as a practice in which thinkers past and present, familiar and unfamiliar, indigenous and subaltern, "Western" and "non-Western" are engaged. At the same time, it takes these very categories and the comparative frames they generate as a subject of critical analysis.

Euben's particular area of research lies at the intersection of Euro-American and Islamic political thought. She is the author of Enemy in the Mirror: Islamic Fundamentalism and the Limits of Modern Rationalism (Princeton University Press 1999), Journeys to the Other Shore: Muslim and Western Travelers in Search of Knowledge (Princeton University Press 2006), and Princeton Readings in Islamist Thought: Texts and Contexts from Al-Banna to Bin Laden (Princeton University Press 2009), written and edited with Muhammad Qasim Zaman. She has also published articles in many leading academic journals.

Euben's honors include fellowships from the NEH, the Radcliffe Institute for Advanced
Study, the American Council of Learned Societies, and the Mellon Foundation. She was awarded the Frank L. Wilson Best APSA Paper Prize, and has received a teaching award from Wellesley College (2003) and the University of South Carolina (1996). Euben is currently a member of the APSA Council, the APSR Editorial Board, and the Executive Editorial Committee of Political Theory.

Why has the experience and act of humiliation come to be so closely associated with the bodies and minds of Muslims in this political and historical moment? In what, precisely, does this humiliation consist? Euben's Guggenheim Fellowship project approaches these questions by investigating both Islamist discourse about the humiliation of Islam and American rhetoric of national humiliation by Muslims. She traces patterns and discontinuities in the content and significance of humiliation across Islamist discourses, competing Arabic discourses of humiliation, and in the Islamic tradition in whose name Islamists routinely claim to speak. And, finally, she analyzes what rhetorics of humiliation do-that is, how they work politically and affectively on particular audiences in specific contexts-as well as what they say. The project will at once demonstrate that the association between humiliation and retaliation evinced in Islamist discourse is far from inevitable, and contribute to a conception of humiliation grounded in overlaps among historically and culturally situated understandings and ethical grammars.

\section{DIANA C. MUTZ}

Diana C. Mutz holds the Samuel A. Stouffer Chair in Political Science and Communication, and also serves as director of the Institute for the Study of Citizens and Politics at the University of Pennsylvania. Her current research involves the psychology of American attitudes toward globalization. In 2011, Mutz received the Lifetime Career

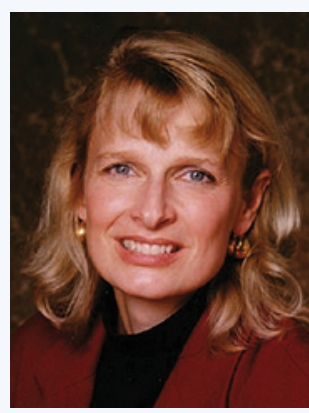
Achievement Award in Political Communication from APSA. She was inducted as a Fellow of the American Academy of Arts and Sciences in 2008. 
An award-winning author, she wrote Impersonal Influence: How Perceptions of Mass Collectives Affect Political Attitudes (Cambridge University Press 1998), a book awarded the Robert Lane Prize for the Best Book in Political Psychology, and the 2004 Doris Graber Prize for Most Influential Book on Political Communication published in the last 10 years. In 2006, she published Hearing the Other Side: Deliberative Versus Participatory Democracy (Cambridge University
Press 2006) which was awarded the 2007 Goldsmith Prize by Harvard University and the Robert Lane Prize for the Best Book in Political Psychology. Mutz's latest book, In-Your-Face Politics: The Consequences of Uncivil Media, was published by Princeton University Press in 2015. Mutz has also published articles in a variety of leading academic journals.

Mutz served as founding co-PI of Timesharing Experiments for the Social Sciences
(TESS), an interdisciplinary infrastructure project that continues to promote methodological innovation across the social sciences. This project received the Warren Mitofsky Innovator Award in 2007. She subsequently wrote Population-Based Survey Experiments (Princeton University Press 2011), which offers the first booklength treatment of this new method drawing on examples from across the social sciences. 